\title{
Seroprevalance of Chlamydophila abortus Infections in Goats in Burdur Province
}

\author{
Burdur İlinde Keģilerde Chlamdophila abortus Enfeksiyonunun Seroprevalanst
}

\author{
Mehmet KAYA1 ${ }^{1}$, Dilek ÖZTÜRK ${ }^{*}[\mathbb{D}$ \\ ${ }^{1}$ Mehmet Akif Ersoy University, Faculty of Veterinary Medicine, Department of Microbiology, Burdur, Turkey
}

\begin{abstract}
Chlamydophila abortus is the causative agent of enzootic abortion (OEA) in sheep that causes severe economic loss in sheep and goat breeding worldwide. The aim of this study was to detect the seroprevalence of $C$. abortus infection in goat flocks in Burdur province of Turkey. A total of 384 blood serum samples were collected from two years and older goat in randomly selected 22 goat flocks. The apparent and true seroprevalences of individual, withinflock and between- flocks of the C. abortus infection were determined in goats by a commercial the enzyme linked immunosorbent assay (ELISA) kit. The apparent and true seroprevalence of C. abortus individual, within- flock and between-flocks was calculated as $19.27 \%, 22.77 \%, 86.36 \%$ and $19.44 \%, 23.16 \%$ and $90.81 \%$, respectively. The seropositivity of $C$. abortus infection to according to flock size were statistically significant $(\mathrm{p}<0.05)$ between some goat flocks. There was no statistically significant difference between goat breed and C. abortus infection ( $\mathrm{p}>0.05)$. In conclusion, these findings showed that $C$. abortus infection is found high rates in goat flocks in Burdur and the control and eradication programs should be started to prevent the spreading of C. abortus.
\end{abstract}

Keywords: Chlamydophila abortus, ELISA, Goat, Seroprevalence.

Öz: Chlamydophila abortus, tüm dünyada koyun ve keçilerde ciddi ekonomik kayıplara yol açan, koyunların enzootik abortusunun (OEA) etkenidir. Bu çalışmanın amacı, Türkiye'nin Burdur ilinde keçi sürülerinde C. abortus enfeksiyonunun seroprevalansını belirlemektir. Toplam 384 kan serum örneği, rastgele seçilen 22 keçi sürüsünde, 2 ve daha büyük yaşlardaki keçilerden toplandi. C. abortus enfeksiyonunun bireysel, sürü içi ve sürüler arası seroprevalansı, ticari bir enzyme linked immunosorbent assay (ELISA) kiti ile belirlendi. C. abortus'un görünen ve gerçek bireysel, sürü içi ve sürüler arası seroprevalansı sirasiyla $19.27 \%, 22.77 \%, 86.36 \%$ ve $19.44 \%, 23.16 \%, 90.81 \%$ olarak hesapland1. Sürü büyüklüğüne göre $C$. abortus enfeksiyonunun seropozitifliği bazı sürüler arasında istatistiki olarak önemli $(\mathrm{p}<0.05)$ bulundu. Keçi ırkları ile C. abortus enfeksiyonu arasındaki ilişki önemli bulunmadı ( $\mathrm{p}>0.05)$. Sonuç olarak, C. abortus enfeksiyonunun Burdur ilinde bulunan keçi sürülerinde yüksek oranda bulunduğu, C. abortus enfeksiyonunun yayılımını önlemek için kontrol ve eradikasyon çalışmalarına hemen başlanması gerektiği kanaatine varild1.

\begin{tabular}{ll}
\hline \multicolumn{2}{l}{ Anahtar Kelimeler: Cblamydophila abortus, ELISA, Keçi, Seroprevalans. } \\
\hline${ }^{*}$ Corresponding author : Dilek ÖZTÜRK & e-mail : dozturk@mehmetakif.edu.tr \\
Geliş tarihi / Received : 12.02.2020 & Kabul tarihi / Accepted: 16.03.2020 \\
\hline
\end{tabular}

\section{Introduction}

Ovine enzootic abortion (OEA) is a chronic disease caused by Chlamydophila abortus (C. abortus). C. abortus is a compulsory intracellular bacterium that causes abortion, stillbirth and poor offspring in small ruminants. C. abortus leads to significant economic losses in sheep and goat flocks in all over the world (Aydın and Paracikoğlu, 2006). C. abortus causes usually abortions in 2-3 weeks before birth (Kalender et al., 2013). Subclinical infection can be transmitted to healthy animals and flocks through the placenta, vaginal discharge and aborted fetus of infected animals (Kalender et al., 2013). C. abortus is a zoonotic agent that can cause infections in humans, too. C. abortus can cause abortion in pregnant women in close contact with aborted sheep and goats (Kerr et al., 2005; Pospischil 2006). In addition, breeders, veterinarians, slaughterhouse workers, workers in 
the vaccine production and laboratory workers can be infected by inhalation, taking into account the effects of urine, fecal and fetal fluids of infected animals (Hadley et al., 1992; Cislakova et al., 2007; Ortega et al., 2016).

The diagnosis of infection is made by direct and indirect diagnostic methods. Direct diagnostic methods are intended to demonstrate the presence of the agent. The isolation is the gold standard (Cantekin et al., 2015; Essig and Longbottom, 2015). But, C. abortus is a compulsory intracellular bacterium and it can not breed in the media, so isolation only involves culturing clinical specimens in laboratory animals, or tissue cultures or embriyonated chicken eggs (Aydın and Paracıkoğlu 2006; Cantekin et al., 2015). The isolation is not routinely performed because of the time consuming as well as the expert staff (Cantekin et al., 2015; OIE 2012, Beckman, 2019). The serologic tests are often used in diagnosis of infection. Complement fixation test (CFT) is a test used in the diagnosis of $C$. abortus infection and recommended by OIE (2012). But, cross reaction is detected between Gram negative bacteria such as C. abortus, C. pecorum and Acinetobacter sp. is low the sensitivity and specificity of test (OIE 2012). ELISA, a more sensitive and specific test than CFT, is frequently used in the detection of $C$. abortus infection in field and experimental studies (Vlahovic et al., 2001; Longbottom and Coulter, 2003). Its application is easy, cheap and at the same time testing a large number of animals and getting the results in a short time is the biggest advantage (Villagro-Blanco et al., 2015, OIE 2012).

The seroprevalence of $C$. abortus infection in sheep has been reported $1.81 \%-32 \%$ in Turkey (Duman and Durak, 1998; Baz and Aydın, 2006; Caya et al., 2006; Küçükkayan et al., 2007; Otlu et al., 2007; Öztürk et al., 2016). In Burdur, there are two studies on the prevalence of $C$. abortus infection in sheep and cattle using ELISA (Öztürk et al., 2012; Öztürk et al., 2016). In these studies, C. abortus infection could not detectable in cattle, but the prevalence of individual, within-flocks and between flocks in sheep were $32 \%, 40 \%$ and $80 \%$, respectively. Although presence of C. abortus infection in goats has known, the seroprevalence of $C$. abortus in goats had not been investigated in Turkey before.

The aim of the present study was to determine the apparent and true prevalence of C. abortus infection in goat flocks in Burdur province of Turkey.

\section{Materials and Methods}

\section{Sampling}

This study was conducted in between October 2016 and January 2017. The blood serum samples were collected from 22 goat flocks (Hair goat:12, Honaml goat: 10) found least 20 goat with aged 2 years and older female goats, according to records of the Burdur Association of Sheep and Goat Breeders. The size of the flocks were changed between 40-500 animals. The goats were selected with random sampling method from flocks. The flock information used in this study was given in Table 1. Burdur province, which is located in southwest of Turkey is approximately $7,135 \mathrm{~km}^{2}$ and a crossing area between Aegean, Middle Anatolia and Mediterranean parts of Turkey. The mean altitude is $1000 \mathrm{~m}$ above sea level.

In order to determine the prevalence rate without error, the sample size was determined according to epidemiological criteria. Since there was no study on seroprevalence of $C$. abortus in goats in Burdur province of Turkey, the estimated prevalence was accepted as 50\% (Erganiş and Uçan, 2001). The minimum number of samples to be used in the survey according to $95 \%$ confidence interval and 5\% error margin was determined as 384 (Erganiş and Uçan 2001). The 384 serum samples were collected from 11 to 20 goats in each flocks between October 2016 and January 2017. Blood samples were collected in $10 \mathrm{ml}$ vacutainer tubes from the juguler vein of goats. Blood samples were transported to Burdur Mehmet Akif Ersoy University Faculty of Veterinary Medicine, Department of Microbiology Laboratory. The samples were centrifuged for 5 minutes at $5000 \mathrm{x}$ 
$\mathrm{g}$ and the serum samples were stored at $-20^{\circ} \mathrm{C}$ until using.

\section{ELISA}

The serum samples were tested for C. abortus antibodies using a commercial ELISA kit (IDEXX, Switzerland, Liebefeld-Bern, Switzerland) according to the manufacturer's instructions. The absorbance value (OD) of each well was read in a $450 \mathrm{~nm}$ ELISA reader (Microplate Reader RT-2100C, Rayto and Analytical Sciences Co Ltd, PRC). The mean OD values of the positive (PC) and negative controls
(NC) were calculated. According to the kit protocol, the test was accepted as valid if the mean value of $\mathrm{PC}(\mathrm{PCx})$ was $\leq 2,000$, the mean value of $\mathrm{NC}(\mathrm{NCx})$ was $\leq 0,500$ and $\mathrm{PCx}-\mathrm{NCx} \geq 0,300$. The ratio $\mathrm{S} / \mathrm{P}(\% \mathrm{~S} / \mathrm{P})$ for each sera sample was calculated according to the following formula. Example P / S \% = Example- NCx- / PCx-NCx$\mathrm{X} 100$. The $\mathrm{S} / \mathrm{P}$ ratios of sera samples were evaluated as negative $\leq 30 \%, 30 \%-40 \%$ suspicious, and $\geq 40 \%$ positive for $C$. abortus antibodies. The flocks in which at least one seropositive animals for $C$. abortus were accepted to "positive flocks".

Table 1. The villages according to numbers of samples and herd size in this study

\begin{tabular}{llcc}
\hline & \multicolumn{1}{c}{ Villages } & Number of blood samples & Herd sizes \\
\hline 1 & Kayis/Central village & 20 & 430 \\
2 & Kayis/Central village & 20 & 160 \\
3 & Kayis /Central village & 20 & 300 \\
4 & Kayis /Central village & 20 & 350 \\
5 & Cine /Central village & 12 & 100 \\
6 & Tas kapi/ Central village & 20 & 40 \\
7 & MAKU goat farm /Central village & 20 & 250 \\
8 & Guneyyayla /Central village & 10 & 40 \\
9 & Guneyyayla /Central village & 10 & 40 \\
10 & Guneyyayla /Central village & 11 & 45 \\
11 & Yarisli /Yesilova & 20 & 230 \\
12 & Kayadibi /Yesilova & 20 & 205 \\
13 & Kayadibi /Yesilova & 20 & 230 \\
14 & Harmanli/Yesilova & 20 & 300 \\
15 & Kartalpinar & 20 & 164 \\
16 & Bolmepinar/Cavdir & 20 & 300 \\
17 & Cavdir & 18 & 500 \\
18 & Kizillar / Cavdir & 20 & 350 \\
19 & Bayir / Cavdir & 19 & 430 \\
20 & Bayir / Cavdir & 12 & 250 \\
21 & Karakoy / Cavdir & 14 & 212 \\
22 & Cavdir & 18 & 170 \\
\hline & Total & $\mathbf{3 8 4}$ & \\
\hline & & & $\mathbf{5 0 9 6}$ \\
\hline
\end{tabular}

\section{Calculation of appearent prevalence}

The appearent individual, within-flock and between- flock prevalence was calculated in 95\% confident interval (GA) according to the Wilson binominol estimation method (Brown et al., 2001).

\section{Calculation of true prevalence}

To cite this article: Kaya M, Öztürk. D. (2020). Seroprevalance of Chlamydopbila Abortus Infections in Goats in Burdur Province. MAKU J. Health Sci. Inst., 8(1), $1-10$ 
The true individual, within- flock and betweenflock prevalence was calculated according to the Rogan-Gladen estimation method (Rogan and Gladen, 1978). In the calculations, Idexx Chlamydiosis Total Ab Test kit manufacturer (IDEXX) was used in 95\% sensitivity and 99\% specificity which is reported for the goats.

\section{Statistical analysis}

First, the data were entered in SPSS computer statistical program and whether serum samples collected from the flocks showed normal distribution was determined by One Sample
Kolmogorov-Smirnov test. The association between the seroprevalence of $C$. abortus infection and flock size were calculated using the Chi-square test $\left(\chi^{2}\right.$-test). The relation between the flock size and the seroprevalence of infection rate was tested by simple linear regression.

\section{Questionnairs}

A questionnaire was carried out with goat owners (flock size, age, breeding and reproductive disorders such as stillbirths and abortions. The village names, sample numbers, size of flock was given in Table 1-2.

Table 2. Distrubition of C. abortus seroprevalances in goat herds

\begin{tabular}{cccccccc}
\hline & \multicolumn{2}{c}{ Number of herds $(\mathbf{N}=\mathbf{2 2})$} & \multicolumn{2}{c}{ Number of sample (N=384) } \\
\hline & Positive & & Negative & & Positive & \multicolumn{1}{c}{ Negative } \\
\hline N & $\%$ & N & $\%$ & N & $\%$ & N & $\%$ \\
\hline 19 & 86.36 & 3 & 13.64 & 74 & 19.27 & 310 & 80.73 \\
\hline
\end{tabular}

$\mathrm{N}$ : Number of animals

\section{Results}

\section{Questionnaire results:}

In this study, the serum samples were collected from Hair (n:12) and Honamli (n:10) goat flocks. The age of goats were no known, but blood samples were collected from 384 goat older than 2 years. The flock owners reported that 16 out of 22 flocks had abortions and died within a few days after birth of kids in 15 flocks.

\section{ELISA results}

The seroprevalence for $C$. abortus infection in goats were determined to be $19.27 \%(74 / 384)$ (Table 3). The seropositivity was detected in 19 of 22 goat flocks. The seroprevalence of infection were changed from $5 \%$ to $60 \%$ in the positive goat flocks (Table 2 and 3). While only five of the positive flocks had one seropositive animal and fourteen flocks had two or more positive animals (Table 3). The seropositivity for C. abortus was determined in 4 of the 5 flocks that had no reproductive problems.

In this study, the serum samples were collected from Hair and Honamli goat flocks. Seropositivity for C. abortus in Hair and Honamli goats were detected in $15.5 \%$ and $23.34 \%$, respectively (Table 4). The relationship between goat breed and C. abortus infection was evaluated statistically. 
Table 3. Sizes, number of aborted fetus and stillbirth and ELISA results in goat herds for C. abortus.

\begin{tabular}{|c|c|c|c|c|c|c|c|c|c|c|}
\hline \multirow[t]{2}{*}{ Herds no } & \multirow{2}{*}{$\begin{array}{c}\text { Herd sizes } \\
\mathrm{N}\end{array}$} & \multicolumn{2}{|c|}{$\begin{array}{c}\text { Aborted } \\
\text { goat }\end{array}$} & \multicolumn{2}{|c|}{ Stillbirth } & \multicolumn{2}{|c|}{$\begin{array}{c}\text { ELISA } \\
\text { positive }\end{array}$} & \multicolumn{2}{|c|}{$\begin{array}{c}\text { ELISA } \\
\text { negative }\end{array}$} & \multirow{2}{*}{$\begin{array}{c}\text { Number } \\
\text { of } \\
\text { samples }\end{array}$} \\
\hline & & $\mathrm{N}$ & $\%$ & $\mathrm{~N}$ & $\%$ & $\mathrm{~N}$ & $\%$ & $\mathrm{~N}$ & $\%$ & \\
\hline 1 & 430 & 35 & 8.14 & 11 & 2.6 & 3 & 15 & 17 & 85 & 20 \\
\hline 2 & 160 & 10 & 6.25 & 20 & 6.3 & 1 & 5 & 19 & 95 & 20 \\
\hline 3. & 300 & 10 & 3.33 & 20 & 6.7 & 1 & 5 & 19 & 95 & 20 \\
\hline 4. & 350 & 20 & 5.71 & 10 & 2.9 & 5 & 20 & 15 & 80 & 20 \\
\hline 5. & 100 & 15 & 15 & 15 & 15 & 6 & 50 & 6 & 50 & 12 \\
\hline 6. & 40 & 5 & 12.5 & 6 & 15 & 2 & 10 & 18 & 90 & 20 \\
\hline 7. & 250 & 0 & 0 & 0 & 0 & 3 & 15 & 17 & 85 & 20 \\
\hline 8. & 40 & 0 & 0 & 0 & 0 & 2 & 20 & 8 & 80 & 10 \\
\hline 9. & 40 & 0 & 0 & 1 & 2.5 & 5 & 50 & 5 & 50 & 10 \\
\hline 10. & 45 & 3 & 6.7 & 2 & 4.4 & 6 & 54.55 & 5 & 55.45 & 11 \\
\hline 11. & 230 & 0 & 0 & 0 & 0 & 3 & 15 & 17 & 85 & 20 \\
\hline 12. & 205 & 4 & 1.9 & 1 & 0.5 & 12 & 60 & 8 & 40 & 20 \\
\hline 13. & 300 & 20 & 6.7 & 15 & 5 & 2 & 10 & 18 & 90 & 20 \\
\hline 14. & 230 & 6 & 2.6 & 10 & 4.3 & 11 & 55 & 9 & 45 & 20 \\
\hline 15. & 164 & 2 & 1.22 & 0 & 0 & 0 & 0 & 20 & 100 & 20 \\
\hline 16. & 300 & 15 & 5 & 10 & 3.3 & 4 & 20 & 16 & 80 & 20 \\
\hline 17. & 500 & 0 & 0 & 0 & 0 & 1 & 5.55 & 17 & 94.45 & 18 \\
\hline 18. & 350 & 10 & 2.9 & 2 & 0.6 & 0 & 0 & 20 & 100 & 20 \\
\hline 19. & 430 & 0 & 0 & 0 & 0 & 0 & 0 & 19 & 100 & 19 \\
\hline 20. & 212 & 50 & 23.6 & 35 & 16.5 & 1 & 7.14 & 13 & 92.86 & 14 \\
\hline 21. & 170 & 50 & 29.4 & 0 & 0 & 1 & 5.56 & 17 & 94.44 & 18 \\
\hline 22. & 250 & 50 & 20 & 10 & 4 & 5 & 41.67 & 7 & 58.33 & 12 \\
\hline Total & 5096 & 295 & 5.8 & 168 & 3.3 & 74 & 19.27 & 310 & 80.73 & 384 \\
\hline
\end{tabular}

N: Number of animals

\section{Apparent and true prevalence results}

Table 4. Distribution of C. abortus seroprevalence in goats
In this study, the apparent the individual, withinflock and between- flocks prevalence values for $C$. abortus infection in the goats were calculated to be $19.27 \%$ (95\% GA: $15.64 \%-23.51 \%$ ), $22.77 \%$ (95\% GA: 18.54-27.63\%) and 86.36\% 95\% GA: $66.67 \%-95.25 \%$ ), respectively (Table 5). By the spesificity and sensitivity of $C$. abortus ELISA kit, the true individual, within-flock and between-flock prevalence values for $C$. abortus infection were detected 19.44\%(95\%GA:15.24-23.63), 23.16\%(95\% GA:18.31-28.01), 90.81\% (95\% GA: \%75.56-106.07), respectively (Table 5). 
Table 5. The prevalance apparent and true individual, within-herd and between-herd in goats.

\begin{tabular}{|c|c|c|c|c|c|c|}
\hline & & & \multicolumn{2}{|c|}{ Apparent prevalence } & \multicolumn{2}{|c|}{ True prevalence } \\
\hline & & & $\begin{array}{c}\text { Estimated } \\
(\%)\end{array}$ & $\% 95$ GA & $\begin{array}{c}\text { Estimated } \\
(\%)\end{array}$ & $\% 95$ GA \\
\hline Prevalence & Samples & Positive & & & & \\
\hline Individual & 384 & 74 & 19.27 & $15.64-23.51$ & 19.44 & $15.24-23.63$ \\
\hline Within-herd & 335 & 74 & 22.09 & $17.98-26.83$ & 22.44 & $17.71-27.16$ \\
\hline $\begin{array}{l}\text { Between- } \\
\text { herd }\end{array}$ & 22 & 19 & 86.36 & $66.67-95.25$ & 90.81 & $75.56-106.07$ \\
\hline
\end{tabular}

\section{Statistical analysis}

The highest prevalence of $C$. abortus infection was $29 \%$ in the flock had 120-239 aminals. The lowest prevalence of infection was $9 \%$ in the largest flock size group that had over 340 animals. The difference $(\mathrm{P}<0.05)$ between the values carrying different letters in the same column was found significant (Table 6).

The range of seropositivity for C. abortus was showed differences in goat flocks (Table 4). The difference in the prevalence of $C$. abortus infection between the goat breed was not statistically significant $(\mathrm{P}>0.05)$.

Table 6. Seroprevalence of C. abortus infection in goats according to flock size in Burdur province.

\begin{tabular}{lcccc}
\hline Size of flock & $\begin{array}{c}\text { Number of } \\
\text { flocks }\end{array}$ & Number tested & $\begin{array}{c}\text { Seropositives } \\
\mathbf{( \% )}\end{array}$ & $\begin{array}{c}\text { Rate of } \\
\text { seropositive (\%) }\end{array}$ \\
\hline $40-119$ & 5 & 63 & $21^{\mathrm{a}}$ & $10-54.55$ \\
$120-249$ & 7 & 132 & $29^{\mathrm{ac}}$ & $0-60$ \\
$250-339$ & 5 & 92 & $15^{\mathrm{bc}}$ & $5-41.67$ \\
$340-500$ & 5 & 97 & $9^{\mathrm{b}}$ & $0-20$ \\
\hline Total & 21 & 384 & 19.27 & $0-60$ \\
\hline
\end{tabular}

$* \mathrm{P}<0.05$ : The difference $(\mathrm{P}<0.05)$ between the values carrying different letters in the same column was found significant.

\section{Discussion}

there are no studies to determine the

Chlamydophila abortus is responsible for abortion, infertility, keratoconjunctivitis, pneumonia, enteritis, mastitis and arthritis in ruminants (Reinhold et al., 2011). The seroprevalence of $C$. abortus infection have been usually investigated in sheep in Turkey (Baz and Aydın, 2006; Duman 1996; Caya et al., 2006; Gokce et al., 2007; Otlu et al., 2007; Muz et al., 2014). Although the presence of $C$. abortus infection has been known for a long time in goats of Turkey (Kalender et al., 2013) seroprevalence of $C$. abortus infection in goats.

In this study, the flock owners reported that 16 out of 22 flocks had abortions and died within a few days after birth of kids in 15 flocks. Out of 22 flocks, 19 were positive for $C$. abortus antibodies. The abortion was detected in 2 out of 3 negative flocks for C. abortus antibodies. In Turkey, the high prevalence of abortion cases in small ruminants is due to generally brucellosis (Arda et 
al., 1987; Küçükkayan et al., 2007; Otlu et al., 2007). But, the etiological agents as C. burnetii, T. gondii, Leptospira sp., Listeria monocytogenes may cause abortion in small ruminants, too (Arda et al., 1987; Otlu et al., 2007). In this study, the seropositivity were detected in 14 of the flocks with abortion problem and all of the flocks with kid death. ELISA was positive in 4 goat flocks that were considered to be healthy and no reproductive problem such as kid death and abortion. The goat owners were reported that animal movements were high in farms, the animals were taken from random flocks, and history of animals and flocks were unknown. The researchers (Aydin and Paracıkoğlu, 2006) reported that once aborted animals did not abort a second time. However, the animals infected during the late stages of pregnancy can not usually abort, but can develop abortion in next season (Aydın and Paracıkoğlu, 2006).

In this study, the seroprevalence of $C$. abortus infection ranged from $5 \%$ to $60 \%$ in goat flocks. The highest prevalence of $C$. abortus infection was $29 \%$ in the flock had 120-239 aminals. The lowest prevalence of infection was $9 \%$ in the largest flock size group that had over 340 animals. However, there was no statistically significant difference between goat breed and $C$. abortus infection ( $>0$.05). Al Qudah et al. (2004) reported that there was correlation between the seroprevalence of $C$. abortus infection and flock size in sheep flocks, but there was no significant correlation in goat flocks. In this study, the apparent and true prevalence of within-flock of C. abortus infection was determined $22.77 \%$ and $23.16 \%$ in goat flocks, respectively. The apparent prevalence of withinflock of $C$. abortus infection were reported between $11.37 \%-52.9 \%$ in goat flocks (Al-Qudah et al., 2004; Masala et al., 2005; Hernandez et al., 2014, Yin et al., 2014). Hernandez et al. (2014) reported that the prevalence of $C$. abortus infection was $4.87 \%$ in goats and ranged from $3.44 \%$ to $13.51 \%$ in flocks. This rate was mostly low from the present study results. This results can be originated from grown together goat and sheep in the same flocks in Burdur province. The researchers (Aydin and Paracikoglu, 2006; Quinn et al., 2009) reported that the sheep can be source of $C$. abortus infection in goat. In the present study, while the apparent prevalence of individual, within flocks and between- flocks for C. abortus infection was calculated as $19.27 \%, 22.09 \%$ and $70.37 \%$, respectively, true prevalance of $C$. abortus individual, within- flocks and between- flocks was detected $19.44 \%, \quad 22.44 \%$ and $90.81 \%$, respectively. When these results were compared with the study done in sheep of Burdur province, the prevalence of individual, within-flock and between- flocks the seroprevalence of $C$. abortus in goats was found low. The sheep are more susceptible to $C$. abortus infection than the goats (Quinn et al., 2009). In Burdur, goats and sheep are generally grown together in the same flocks. It can be possible that infections are transmitted from sheep to goats. Furthermore, the high seroprevalence of the infection may be due to the lack of studies on protection and control of $C$. abortus infection.

In this study, the apparent and true prevalence of individual for C. abortus infection was calculated as $19.27 \%$ and $19.44 \%$ respectively. The prevalence of $C$. abortus in goats has been investigated in other countries by different serological tests $(20,48,54$, $82,83,94,97,101,104)$. A Belgian study reported that the seroprevalence of $C$. abortus infection in goats was $18.75 \%$ (Yin et al., 2014). The seroprevalence of $C$. abortus infection was reported \% 21.2 in Greece (Bisias et al., 2009), 25.6\% in Iran (Esmaeili et al., 2015). These results were similar to our study results. But, our study results were found lower than that Taiwan (Wang et al., 2001) and Bosnia-Herzegovina (Krkalic et al., 2015). Our study was conducted in random herds, while both studies were conducted in flocks with abortion problems. While the seroprevalence of $C$. abortus infection in goats was found to be $0.22 \%$ in Poland (Czopowicz et al., 2010), 5.8\% in Italy (Masala et al., 2005), 7.7\% in Slovakia (Cislakova et al., 2007), $11.4 \%$ in Jordan (Al-Oudah et al., 2004), 9.3\% in Brasil (Santos et al., 2012), 4.87\% in Mexico (Hernandez et al., 2014), we was detected 19.27\%. The cause of this differences can be differences in 
management of herds, climates, coexistence of sheep and goats, different detection methods, uncontrolled animal moviments and the lack of studies on protection and control of $C$. abortus infection.

In our study, the apparent and true prevalence of between flocks of $C$. abortus infection were 86.36\%-90.81\%, respectively. Yin et al. (2014) reported that the apparent prevalence of between flocks of the infection was $11.11 \%$, while the apparent prevalence of between flocks of $C$. abortus infection in goats was $48.4 \%$ by Masala et al. (2015) and $100 \%$ by Al-Quadah et al. (2004). Samkange et al. (2010) reported that the prevalance of between flocks was changed between $17.2 \%-54 \%$, in goat flocks. However, Czopowicz et al. (2010) was detected $4.2 \%$. In the present study, the prevalence of between flocks of C. abortus infection was higher than other studies, while the prevalence of between flocks of $C$. abortus infection was lower than Al-Quadah (2004)'s study. The differences for C. abortus infection rate can be probably due to the different diagnostic methods, management, uncontrolled animal movements and it may vary depending on the region where the study was conducted (Rekiki et al., 2002; Masala et al., 2005; Güler et al., 2006; Kalender et al., 2013; Osman, 2013).

In conclusion, In Burdur, the apparent and true prevalence of individual, within-flock and between- flocks seroprevalence of C. abortus infection was higher than the other countries. In this context; a control program for C. abortus infection should be planned goat breeding in Turkey

\section{Acknowledgement}

This study was conducted with the approval of Mehmet Akif Ersoy University Experimental Animals Local Ethics Committee (MAKÜHADYEK / 2016-199). Also, this study was derived from the first author's Master Thesis, supported by Burdur Mehmet Akif Ersoy University Scientific Research Projects
Coordination Unit (Project Number: 0385-YL16).

\section{References}

Al-Qudah, K.M., Sharif, L.A., Raouf, R.Y., Hailat, N.Q., Al-Domy, F.M., 2004. Seroprevalence of antibodies to Chlamydophila abortus shown in Awassi sheep and local goats in Jordan. Veterinarni MedicinaCzech 49, 460 - 466.

Arda, M., Bisping, W., Aydın, N., İstanbulluoğlu, E., Akay, O., İzgür, M., Diker, S., 1987. Orta Anadolu Bölgesi koyunlarında abortus olgularının etiyolojisi ve serolojisi üzerinde bir çalışma. Ankara Üniversitesi Veteriner Fakültesi Dergisi 34 (2), 195-206 (In Turkish).

Aydın, N., Paracıkoğlu, J., 2006. Veteriner Mikrobiyoloji (Bakteriyel Hastalıklar) Chlamydia ve Chlamydophila İnfeksiyonlar1, 1. Bask1, İke-Emek Yayınları, Ankara, s: 305-312 (In Turkish).

Baz, E., Aydın, F. 2006. Kars yöresinde atık yapan koyunların kan serumlarında Chlamydia psittacìye karşı oluşan antikorların Komplement Fikzasyon (CF) ve Enzyme-Linked Immunosorbent Assay (ELISA) testleri ile saptanmasi. Kafkas Üniversitesi Veteriner Fakültesi Dergisi 12(2), 129-135 (In Turkish).

Beeckman, D.S.A., Vanrompay, D.C.G., 2009. Zoonotic Chlamydophila psittaci infections from a clinical perspective. Clinical Microbiology and Infection 15, 11 -17 .

Bisias, G., Burriel, A., Boutsini, S., Kritas, S., Leontides, L., 2009. A serological investigation of some abortion causes among small ruminant flocks in Greece. Journal of Veterinary Medicina 8(2), 1-5.

Brown, L.D., Cat, T.T., Dasgupta, A., 2001. Interval estimation for a proportion. Statistical Science 16, 101 133.

Cantekin, Z., Solmaz, H., Ergün, Y., Özmen, M., 2015. Development of Polymerasa Chain Reaction assays with host -specific internal controls for Chlamydophila abortus. Veterinarni Medicina 60 (1), 1-5.

Caya, H., Aslantas, O., Iyisan, A.S., Mirioglu, M., Tunca, S.T., 2006. Investigation of antibodies against Chlamydopbila abortus (Chlamydia psittaci serotype 1) using microcomplement fixation test (mCFT) and EnzymeLinked Immunosorbent Assay (ELISA), Etlik Veteriner Mikrobiyoloji Dergisi 2006, 17, 7-10. 
Cislakova, L., Halanova, M., Kovacova, D., Stefancikova, A., 2007. Occurrence of Antibodies Against Chlamydopbila abortus in Sheep And Goats In The Slovak Republic. Annals of Agricultural and Environmental Medicine 14, 243-245.

Czopowicz, M., Kaba, J., Szalus-Jordanow, O., Nowicki, M., Witkowski, L., Nowicka, D., Frymus, T., 2010. Prevalence of antibodies against Chlamydopbila abortus and Coxiella burnetii in goat herds in Poland. Polish Journal of Veterinary Science, 13 (1), 175-179.

Duman, R.,1996. Konya bölgesindeki koyunlarda atıklara neden olan Chlamydia enfeksiyonlarının serolojik araştırılması. Selçuk Üniv Fen Bil Enst., Doktora tezi, Konya (In Turkish).

Duman, R., Durak., Y., 1998. Investigation on Chlamydia psittaci infections causing abortion in sheep in Konya district using complement fixation test. Turkish Journal of Veterinary and Animal Science 22, 511-515.

Erganiş, O., Uçan, U.S., 2001. Sörvey çalışmalarında örnekleme teknikleri ve örnek sayısının belirlenmesi. Veteriner Epidemiyoloji (Temel Bilgiler), 2. Bask1, S.Ü Veteriner Fakültesi Yayın Ünitesi, Kampüs, Konya (In Turkish).

Essig, A., Longbottom, D., 2015. Chlamydia abortus: New Aspects of Infectious Abortion in Sheep and Potential Risk for Pregnant Women. Current Clinical Microbiology Reports 2 (1), 22-34.

Esmaeili, H., Bolourchi, M., Mokhber-Dezfouli, M.R., 2015. Seroprevalence of Chlamydia abortus infection in sheep and goats in Iran. Israel Journal of Veterinary Medicine 9(2), 73-77.

Gökçe, H.A., Kaçar, C., Genç, O., Sözmen, M., 2007. Seroprevalance of Chlamydophila abortus in aborting ewes and diary cattle in the North -East part of Turkey. Bulletin of Veterinary Institute in Pulawy $51,9-13$.

Güler, L., Hadimli, H.H., Erganiş, O., Ateş, M., Ok, U., Gunduz, K., 2006. Field evaluation of a PCR for the diagnosis of chlamydial abortion in sheep. Veterinary Record 159, 742-745.

Hadley, K.M., Carrington, D., Frew, C.E., Gibson, A.A.M., Hislop, W.S., 1992. Ovine chlamydiosis in an abottoir worker. Journal of Infection 25(1), 105-109.

Kalender, H., Kılıç, A., Eröksüz, H., Muz, A., K1lınç, Ü., Taşdemir, B. 2013. Identification of Chlamydophila abortus infection in aborting ewes and goats in Eastern Turkey. Revue de Medecine Veterinaire 164(6), 295-301.

Kerr, K., Entrican, G., McKeever, D., Longbottom, D., 2005. Immunopathology of Chlamydophila abortus infection in sheep and mice. Research in Veterinary Science 78, 1-7.

Krkalic, L., Satrovic, E., Goletic, T., Dzaja, P., Severin, K., 2015. Chlamydophila abortus infection in a flock of goats in Bosnia and Herzegovina - a case report. Vet Arbiv, 85 (3), 359 - 368.

Küçükayan, U., Dakman, A., Ülker, U., Müştak, K., 2007. Koyun kan serumu ve fetuslarının bakteriyel atık etkenleri yönünden incelenmesi. Etlik Veteriner Mikrobiyoloji Dergisi 18, 11-16 (InTurkish).

Longbottom, D., Livingstone, M., 2006. Vaccination against chlamydial infections of man and animals. Veterinary Journal 171 (2), 263-275.

Masala, G., Porcu, R., Sanna, G., Tanda, A., Tola, S., 2005. Role of Chlamydopbila abortus in ovine and caprine abortion in Sardinia, Italy. Veterinary Research Communications 29 (Suppl 1), 117-123.

Muz, A., Öngör, H., Gödekmerdan, A., Karahan, M. 2014. Hayvancilıkla Uğraşan Kişilerde İmmunofluoresans Testi (IFA) ile Klamidyoz Antikorlarının Araştırılması. Türk Mikrobiyoloji Cemiyeti Dergisi 44(1), 43-46 (In Turkish).

Otlu, S., Şahin, M., Unver, A., Çelebi, Ö., 2007. Detection of Brucella melitensis and Chlamydophila abortus antibodies in aborting sheep in the Kars province of Turkey. Bulletin of Veterinary Institute in Pulawy 51, 493-495.

Ortega, N., Caro, M.R., Gallego, M.C., MurciaBelmonte, A., Alvarez, D., Rio, L., Cuello, F., Buendia, A.J., Salinas, J., 2016. Isolation of Chlamydia abortus from a laboratory worker diagnosed with atypical pneumonia. Irish Veterinary Journal 69(8), 1-4.

Osman, W A., 2013. Comparative evaluation of indirect ELISA, CF test and PCR for diagnosis of ovine enzootic abortion (Ovine chlamydophilosis). Global Veterinaria 11(1), 65-70.

Öztürk, D., Türütoğlu, H., Kaya, M., 2016. Burdur ilindeki koyunlarda Chlamydophila abortus enfeksiyonunun seroprevalansı. Mehmet Akif Ersoy Üniversitesi Veteriner Fakültesi Dergisi 1(2), 17-20 (In Turkish).

Öztürk, D., Kale, M., Pehlivanoğlu, F., Hasircioglu, S., Türütoğlu, H. 2012. Evaluation for Some Bacterial and Viral Abortions of Dairy Cattle Farms in Burdur District of Turkey. Kafkas Üniversitesi Veteriner Fakültesi Dergisi 18(2), 255-258 (In Turkish).

Pospischil, A., 2006. Enzootic abortion in ewes: A review of recent developments in diagnostics. Small Rum Res., 62 (1-2), 113-115. 
Quinn, P.J., Markey, B.K., Carter, M.E., Donnely, W.J., Leonard, F.C., 2009. Veterinary Microbiology and Microbial Disease, second edition, Blackwell Publishing, UK, 196-202.

Rekiki, A., Sıd1-Boumedıne, K., Sourıa, A., Jemaa Jemli, J., Hammami, S., Rodolakis, A., 2002. Isolation and characterisation of local strains of Chlamydophila abortus (Chlamydia psittaci serotype 1) from Tunisia. Vet. Res., 33, 215-222.

Rogan, W.J., Gladen, B., 1978. Estimating prevalence from the results of a screening test. Am J Epidemiol., 107, 71-76.

Santos, C.S.A.B., Piatti, R.M., Azevedo, S.S., Alves, C.J., Higino, S.S.S., Silva, M.L.C.R., Brasil, A.W.L. and Gennari, S.M., 2012. Seroprevalence and risk factors associated with Chlamydophila abortus infection in dairy goats in the Northeast of Brazil. Pesq. Vet. Bras., 32(11), 1082-1086.

Samkange, A., Katsande, T.C., Tjipura-Zaire, G., Crafford, J.E., 2010. Seroprevalence sur- vey of Chlamydophila abortus infection in breeding goats on commercial farms in the Otavi veterinary district, northern Namibia, Onderstepoort. J Vet Res., 77, 1-5. Travnicek, M., Kovacova, D., Bhide, M.R., Zubricky, B., Cislakova, L., 2002. Field evaluation of an iELISA and CF test for detection of IgG antibodies against Chlamydophila abortus in goats, sheep and rams. Vet-Med Czech, 7, 195-198.

Vlahovic, K., Dove, A., Zupancic, Z., Pavlak, M., Jercic, J., 2001. Comparison of serological procedures for diagnosis of infection with Chlamydophila sp. in bovines. Vet Arhiv., 71(6), 367-379.

Villagro-Blanco, R., Dolz, G., Montero-Caballero, D., and Romero-Zuniga, J.J., 2015. Detection of antibdies against Chlamydophila abortus in Costa Rican sheep flocks. Open Veterinary J., 5(2), 122-126.

Wang, F., Shieh, H., Liao, Y.K. 2001. Prevalence of Chlamydophila abortus Infection in domesticated in ruminants in Taiwan. J Vet Med Sci., 63(11), 1215-1220.

World Organisation for Animal Health (OIE) 2012. Chapter-2.7.7. Enzootic abortion of ewes. Manuel of Diagnosis tests and vaccines for terrestrial animals. p. $1-9$.

Yin, L., Schautteet, K., Kalmar, I.D., Bertels, G., Driessche, E.V., Czaplicki, G., Borel, N., Longbottom, D., Fretin, D., Dispas, M., Vanrompay, D., 2014. Prevalence of Chlamydia abortus in Belgian ruminants. Vlaams Diergeneesk Tijdschr., $83,164-170$.
Zhao, G.H., Shang, C.C., Zhao, Y.Q., Gao, M., Fan, G.Y., Tian, T.T., Yao, Y.L., Chen, D.K., Zhu, X.Q., 2012. Seroprevalence of chlamydial infection in dairy goats in Shaanxi Province, Northwestern China. Afr J Biotech. 11(7), 1796-1799. 